\title{
Identitas Visual Sebagai Sebuah Cara untuk Memperkenalkan Inovasi Ekowisata Kemaritiman
}

\author{
Kartika Kusuma Wardani, Hertina Susandari, Anggra Ayu Rucitra dan Puspita Sari Sukardani \\ Departemen Desain Komunikasi Visual, Fakultas Desain Kreatif dan Bisnis Digital, Institut Teknologi \\ Sepuluh Nopember, Surabaya, Indonesia \\ e-mail: kartikawardani.its@gmail.com
}

\begin{abstract}
Abstrak-Kepariwisataan merupakan salah satu sektor perekonomian yang menyumbang devisa terbesar di Indonesia. Indonesia sebagai negara kepulauan terbesar di dunia memiliki garis pantai yang terbentang panjang dan sangat potensial dalam pengembangan kawasan ekowisata berbasis kemaritiman. ITS sebagai kampus dengan orientasi penelitian dalam bidang kemaritiman mengembangkan bentuk penerapan teknologi akuakultur Ocean-Farm ITS dengan penambahan fungsi sebagai area ekowisata terapung baru lepas pantai. Keberlanjutan dalam penelitian tersebut membutuhkan sebuah solusi dalam memperkenalkan jenis wisata baru dan inovatif sehingga mampu meningkatkan perekonomian daerah dimana teknologi Ocean-Farm ITS diaplikasikan. Dalam tulisan ini, penulis akan menjelaskan tentang solusi identitas visual sebagai sebuah cara dalam memperkenalkan ekowisata baru.
\end{abstract}

Kata Kunci- akuakultur, ekowisata, identitas visual, keramba jaring apung, kemaritiman, matrik morfologi

Abstract-Tourism is one of the economic sectors that contributes the largest foreign exchange in Indonesia. Indonesia as the largest archipelagic country in the world has a long coastline and is very potential in developing maritime-based ecotourism areas. ITS as a campus with a research orientation in the maritime sector develops the application of Ocean-Farm ITS aquaculture technology with the addition of functions as a new floating offshore ecotourism area. Sustainability in this research requires a solution in introducing new and innovative types of tourism so that it can improve the regional economy where ITS Ocean-Farm technology is applied. In this paper, the author will explain about visual identity solutions as a way of introducing new ecotourism.

Keywords - aquaculture, eotourism, visual identity, net cages floating, maritime, morphological matrix

\section{PENDAHULUAN}

Pemerintah Indonesia saat ini sedang mengarahkan fokus pembangunannya secara optimal pada pemanfaatan jasa ekosistem laut dan pesisir termasuk pariwisata bahari dan pesisir [1] Indonesia sebagai negara kepulauan terbesar di dunia memiliki garis pantai yang terbentang panjang dan sangat potensial dalam pengembangan kawasan wisata berbasis kemaritiman disamping memiliki kekayaan dan keragaman dalam bentuk keindahan alam, keragaman ekosistem, hayati, dan budaya. Hal tersebut menjadikan Indonesia sebagai salah satu destinasi pariwisata berbasis kemaritiman yang menarik bagi wisatawan lokal maupun internasional.

Pariwisata dianggap sebagai instrumen pembangunan untuk meningkatkan perekonomian suatu negara dan telah menjadi bagian dari industri global [1]. Kepariwisataan dalam beberapa tahun ini merupakan salah satu sektor perekonomian yang menyumbang devisa terbesar di Indonesia. Berkaitan dengan aspek ekonomi tersebut, sektor pariwisata juga dikenal sebagai salah satu sektor dengan multiplier effect terbesar [2].

Pariwisata, termasuk wisata pesisir dan bahari serta ekosistemnya sendiri, sangat terkait dan memiliki interaksi yang kompleks [3]. Ekosistem kepariwisataan yang baik akan memberikan hasil ekonomi yang berlipat pada suatu daerah dan berdampak pada kesejahteraan rakyat masyarakat di daerah tersebut.

Wisata bahari dan pesisir merupakan salah satu bentuk pariwisata tertua dan segmen terbesar dalam industri pariwisata [4]. ITS sebagai kampus dengan orientasi penelitian dalam bidang kemaritiman mengembangkan bentuk penerapan teknologi akuakultur Ocean-Farm ITS (OFITS) dengan penambahan fungsi sebagai area ekowisata terapung baru lepas pantai untuk merespon kecenderungan peningkatan pemenuhan kebutuhan di waktu luang masyarakat.

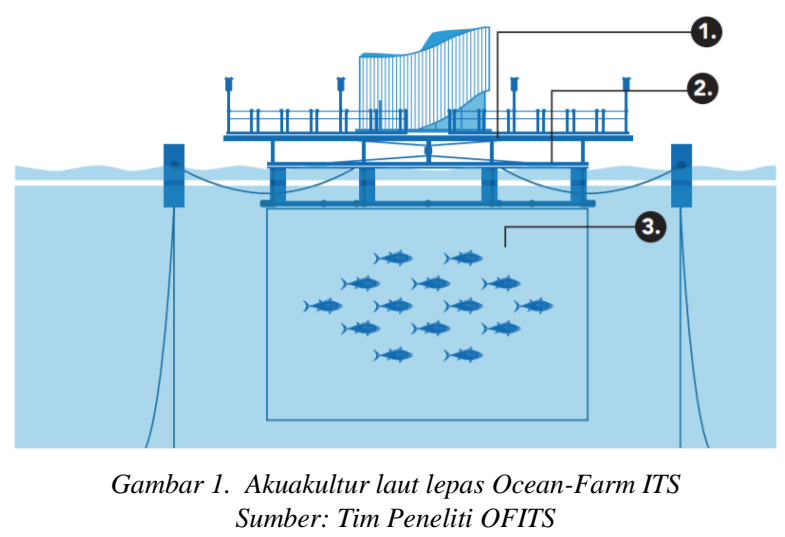

OFITS merupakan sebuah bagunan lepas pantai (Gambar 1) yang terdiri dari 3 (tiga) bagian utama yaitu (1) area multifungsi yang dapat digunakan untuk mendukung kegiatan ekowisata, seperti: hotel, restoran, museum, titik lokasi menikmati terumbu karang, snorkeling, menyelam dan permainan air lainnya, semua dalam konsep terapung, 
(2) geladak yang dibawahnya merupakan tempat orang mengelola budidaya ikan dan (3) keramba jaring apung (KJA) untuk budidaya ikan lepas pantai.

Inovasi pengembangan bagian atas (bagian ke-1) OFITS sebagai lokasi wisata merupakan bentuk usaha keberlanjutan dalam penelitian dan pengembangan inovasi produk dari hasil penelitian awal yaitu pembuatan KJA lepas pantai untuk budidaya ikan laut seperti berbagai jenis ikan kerapu. Sehingga bisa dikatakan kosep ekowisata kemaritiman adalah posisitioning dari inovasi OFITS. Ekowisata sudah saatnya dikonseptualisasikan secara komprehensif dan dikontekstualisasikan dalam lingkungan lokal untuk secara signifikan mengevaluasi keterkaitan antara lingkungan alam dan masyarakat lokal dan memberikan hasil yang berkelanjutan yang menanggapi kebutuhan masyarakat lokal dan memenuhi tujuan pelestarian lingkungan [5].

Potensi ekowisata yang memiliki dampak berkelanjutan pada inovasi ekowisata berbasis maritime baru sehingga dibutuhkan solusi untuk memperkenalkan inovasi ini kepada khalayak sebagai pembeda dari jenis ekowisata berbasis maritime lainnya. Terdapat hubungan antara peletakan dan identifikasi identitas tempat; identitas visual perusahaan dan struktur fisik serta stimulus; dan komunikasi dan peletakan arsitektur. Menciptakan produk, paket, logo, dan tipografi yang menarik secara visual dianggap sebagai kunci keberhasilan pemasaran. [6].

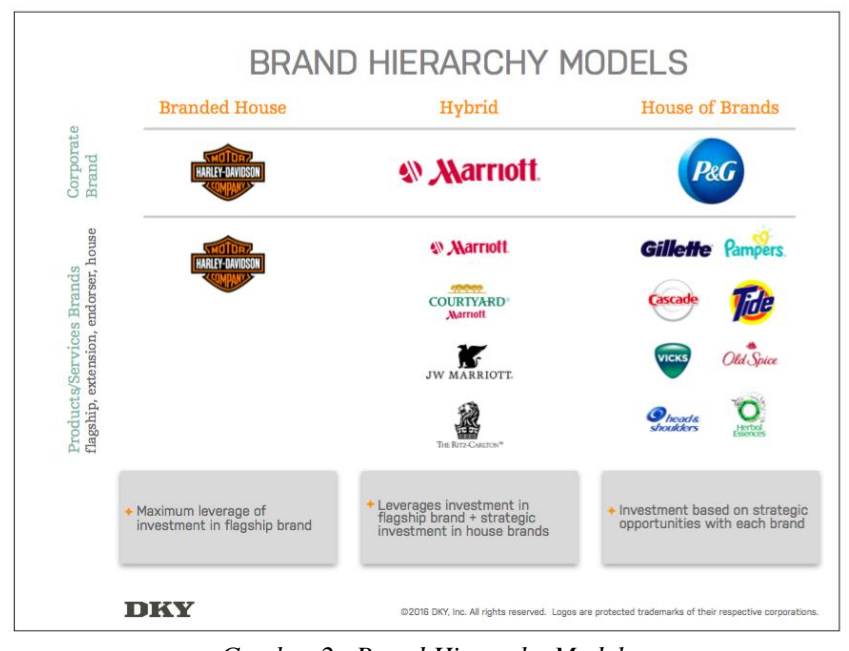

Gambar 2. Brand Hierarchy Models

Perancangan identitas visual untuk pengembangan KJA OFITS yang merupakan corporate brand dalam kerangka arsitektur merek, dan memiliki sebuah produk/layanan brand Trivesea Ecotourism. Arsitektur merek adalah hierarki merek dalam satu perusahaan [7]. Susunan merek-merek dalam arsitektur merek diharapkan memiliki keterikatan antara perusahaan induk, anak perusahaan, produk, dan layanan. Seperti dapat dilihat pada Gambar 2, Hierarki Merek harus menjadi cerminan dari tujuan dan strategi bisnis [8]. Dapat dijelaskan bahwa, model hirarki merek terdiri atas bagian vertical dan horisontal dimana kedua hal tersebuat akan mempertemukan fungsi-fungsi pada setiap merek. Sisi vertikal membagi fungsi merek apakah menjadi merek korporat ataupun merek produk dan servis. Sedangkan sisi horisontal berisi perbedaan jenis merek berkaitan dengan susunan merek produk dan servisnya yaitu branded house, hybrid dan house of brand.

Pendekatan hirarki merek yang digunakan oleh OFITS termasuk dalam house of brand dimana strategi ini memungkinkan setiap merek untuk menetapkan nilai dan makna yang berbeda dengan prospek dan pelanggan. Oleh karena itu kesamaan dalam pengaplikasian merek korporasi dan merek produk atau jasa tidak menjadi keharusan, bahkan dalam kategori ini dapat dikatakan hampir tidak ditemukan pesersamaan yang signifikan dan memungkinkan menghasilkan produk-produk yang tidak saling berhubungan dengan merek korporasinya.

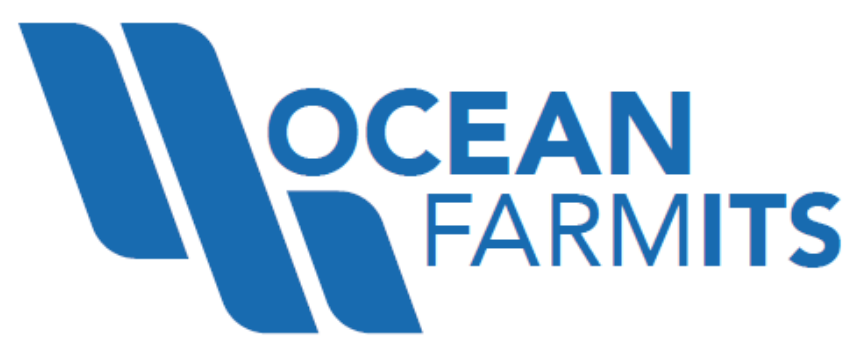

Gambar 3. Logo Akuakultur laut lepas Ocean-Farm ITS Sumber: Tim Peneliti OFITS

Perancangan identitas Trivesea Ecotourism yang akan dilakukan tidak mengacu pada desain merek korporasi OFITS (Gambar 3). Trivesea Ecotourism memiliki sasaran produk/layanan yang sangat berbeda dengan merek korporasi OFITS. OFITS merupakan merek untuk bangunan dasar semi-submersible dengan fungsi utamanya adalah keramba ikan laut. Trivesea Ecotourism menyasar para penggiat dan penikmat ekowisata kelautan yang mengedepankan pemeliharaan ekosistem laut, pemberdayaan masyarakat yang terbuka dengan pengetahuan, pengembangan dan pengaplikasian teknologi baru.

Terkait kebutuhan dalam memebrikan identitas pada Trivesea Ecotourism melalui tulisan ini akan dipaparkan metode pembentukan identitas visual dengan mengaplikasikan metode morphological matrix.

\section{METODE}

Metode yang digunakan dalam membentuk identitas visual dilakukan dengan menggunakan morphological matrix. Morphological matrix adalah sebuah teknik dalam pengorganisasian pikiran, yang merujuk pada pemikiran astrofisikawan [9]. Morphological matrix digunakan desainer untuk mevisualisasikan tujuan perancangan sehingga pesan yang ada dapat dengan mudah tersampaikan.

Matrix ini memiliki dua bagian utama yaitu (1) What? dan (2) How?. What? merupakan komponen-komponen informasi yang terkait dengan objek perancangan. How? adalah solusi yang diketahui atau memungkinkan terkait objek desain. Matrix ini dapat membantu menampilkan bentukan khas, pola, gaya gambar, gaya garis, tipografi, warna dan lain sebagainya sesuai dengan kebutuhan perancang (Gambar 4 dan 5). 


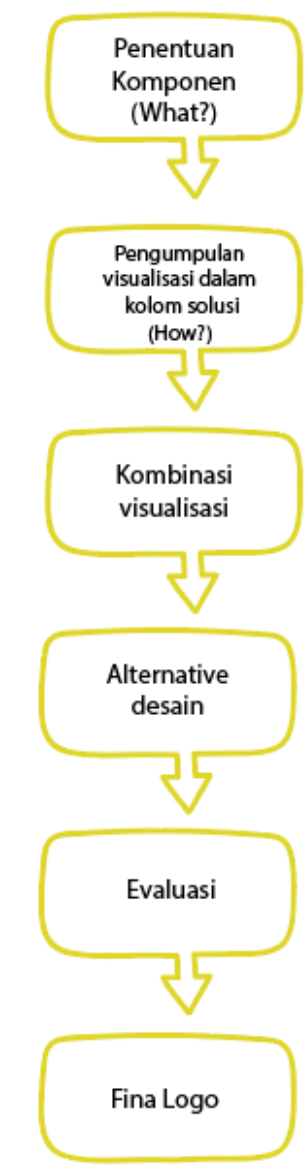

Gambar 4. Metode perancangan logo

Setelah matrix selesai, perancang dapat menggunakan sebagai ide dasar pembuatan identitas dengan cara melakukan seleksi dari varian-varian tiap komponen pada matrix yang telah dibuat. Metode akan menghasilkan berbagai macam alternatif desain yang mengalami proses penyederhanaan bentuk atau reduksi grafis. Reduksi grafis adalah sebuah proses dari translasi gambar dengan prinsip kesederhanaan dan keterbacaan gambar membuatnya sangat cocok untuk piktogram atau logo [10] dan [11].

Alternatif yang telah mengalami reduksi grafis nantinya akan melalui proses eliminasi dan mendapatkaan desain akhir yang diinginkan sesuai dengan tujuan penciptaan identitas visual sebuah area ekowisata bahari pada bangunan OFITS.

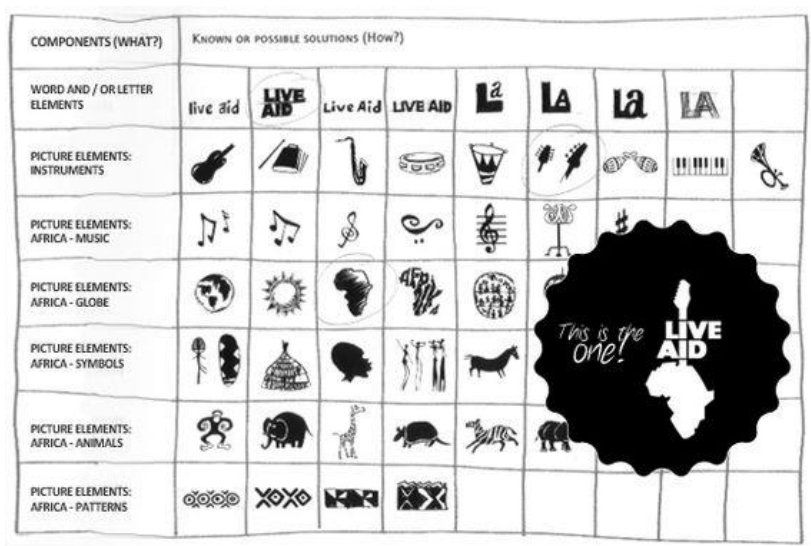

Gambar 5. Morphological Matrix

\section{HASIL DAN PEMBAHASAN}

KJA OFITS merupakan kemasan ekowisata bahari sebagai bentuk inisiasi sinergis pada sektor pangan yang memiliki daya tarik kepariwisataan yang dapat dikelola secara berkelanjutan dan memberikan dampak positif bagi masyarakat sekitar dan ekosistem laut. KJA OFITS ini sebagaimana telah disepakati oleh anggota peneliti dan team desain ditetapkan memiliki nama Trivesea Ecotourism. Pada tulisan ini, tahap dalam penggunaan matrix tersebut diawali dengan mendefinisikan entitas Trivesea Ecotourism menjadi komponen-komponen (what?), sehingga tujuan perancangan dapat tercapai.

Tujuan merancang visual perusahaan/organisasi identitas merek adalah untuk membentuk ekspresi visual dan grafis yang menghubungkan aktivitasnya dengan gambar yang diinginkan [12]. Terkait hal tersebut dapat diketahui karakteristik ekowisata bahari pada teknologi akuakultur OFITS memiliki fungsi, sbb:

1. Budidaya ikan pada ekosistem sesungguhnya di laut lepas.yang berlokasi di bagian pertama KJA OFITS.

Pada bagian fungsi ke dua merupakan area serbaguna yang dapat digunakan sebagai:

2. Lokasi terbaik dalam menikmati keindahan Panorama Pantai dan laut hingga 360 derajat. Pemilihan lokasi yang memiliki pantai yang bersih dan memiliki pemandangan yang indah merupakan konsep sederhana dalam pemanfaatan lantai dua KJA OFITS.

3. Hotel dengan konsep resort privat terapung sebagaimana keunggulan desain KJA OFITS terinspirasi dari bangunan semisubmersible di laut lepas. Bangunan tersebut memiliki ruangan akomodasi yang dapat digunakan untuk menginap.

4. Lokasi untuk mengakomodasi olah raga laut. Potensi olah raga laut cukup besar karena didukung dari kondisi ombak yang tidak terlalu besar disesuaikan dengan area memiliki keindahan bawah laut dalam kondisi baik dapat dilihat berwarna hijau kebiruan dan dekat dengan bibir pantai. Olah raga laut yang dapat dilakukan adalah Menyelam, Ski Air, Selancar, dan Memancing. Kombinasi olah raga laut dan area wisata terapung memiliki fungsi yang saling mendukung satu sama lain. Wisatawan yang melakukan olah raga air di pantai Sidoasri dapat melakukan transit untuk beristirahat dan melanjutkan kegiatan wisata lainnya pada bangunan aquaculture.

5. Lokasi taman bermain air. Permainan ini sangat disukai oleh anak-anak dan banyak diaplikasikan di berbagai negara sebagai pelengkap taman-taman kota. Kolam buatan dengan tinggi air sekitar $15 \mathrm{~cm}$ dilengkapai dengan berbagai permainan anak dan dapat mengeluarkan air dengan bentuk dan kecepatan semburan yang beragam. Permainan ini melatih dan merangsang sistem fisik, motorik dan visual anak, terutama untuk anak batita hingga 10 tahun memiliki manfaat yang besar tidak hanya sebagai sebuah tempat hiburan.

6. Lokasi edukasi kelautan. Peluang kepariwisataan dengan konten edukasi pada KJA OFITS dapat dilakukan dengan berbagai alternatif, yaitu memberikan makan 
ikan baik dari bagian atas KJA maupun pemberian makan dibawah laut didalam area penangkaran ikan, serta pemberian konten edukasi dalam ruang tertutup dengan kombinasi daya tarik visual dan teknologi terkini sebagaimana perkembangan konten museum yang makin interaktif.

7. Lokasi ekowisata terapung yang ramah lingkungan dan memperhatikan keberlanjutan ekosistem sekitar bagungan terapung OFITS yang sangat terkait kegiatan manusia membawa implikasi terhadap kualitas dan kuantitas sumber daya alam.

Pembentukan ekspresi visual menggunakan elemenelemen desain meliputi bentuk, ruang, garis, ukuran, warna,kontras, pola, tekstur, dan tipografi yang berpadu dengan prinsip-prinsip pendukung memengaruhi hubungan internal sebuah desain dan mencakup skala, penekanan, irama, gerakan, kedekatan dan pengulangan. Mendesain identitas merek mendemonstrasikan hubungan antara strategi dan desain, dan menampilkan studi kasus praktik terbaik yang menarik dari sektor publik dan swasta, secara global. Mendesain identitas merek juga terkait dengan strategi merek. Strategi merek yang efektif memberikan ide sentral dan pemersatu di mana semua perilaku, tindakan, dan komunikasi selaras.

Pengembangan konsep identitas ekowisata pada OFITS diawali dengan memahami potensi, karakteristik pengembangan ekowisata bahari dan hubungan antar entitas. Sehingga memiliki perilaku, Tindakan, dan komunikasi yang selaras nantinya apabila sudah diaplikasikan pada media-media branding.

Pemahaman yang bertujuan untuk keselarasan beberapa poin diatas selanjutnya digunakan untuk menggali komponen apa saja yang diletakan dalam matrix berdasarkan elemen kata dan huruf dan elemen gambar. Elemen kata dan huruf merupakan varian yang berhubungan dengan tulisan dan huruf sedang elemen gambar dijabarkan dalam visualisasi terkait laut, hewan laut dan kekayaan hayati laut, kapal, KJA OF ITS, dan ekspresi terkait kegiatan berlibur.

Gambar 6 menjelaskan 30 sketsa solusi yang diketahui dan memungkinkan hasil brainstorming sebagai dasar kreasi desain identitas visual. Pada kolom komponen terdapat elemen kata dan huruf dijabarkan ide mengenai tulisan lowercase, tulisan mengikuti ombak, single font, italic, dan uppercase. Pada elemen gambar laut terdapat garis-garis yang membentuk ombak sederhana, yang ke dua menampilkan cahaya yang masuk kedalam dasar laut, kemudian kondisi laut dengan matahari terbit, selanjutnya ombak besar dengan cipratan airnya dan yang terakhir adalah gambar pantai tampak mata burung dengan beberapa batu karang tinggi.

Pada elemen yang ke tiga adalah hewan laut dan kekayaan hayati laut, yang di wakili dengan penyerderhanaan gambar ikan, penyu laut yang memiliki bentuk khas, biaota laut yang diwakili oleh anemon laut dari jenis snakelocks anemone yang juga memiliki fungsi sebagai tempat tinggal tinggal para ikan. Selanjutnya di elemen yang sama terdapat juga sketsa gambar karang dan selanjutnya adalah barisan burung camar diatas laut.

Elemen ke empat adalah sketsa ide berhubungan dengan kapal. Pada kolom solusi terdapat sketsa bentuk kapal kayu, kapan karet, stir kapal, tali tampar dan bentuk kapal layar dengan layar terkembang. Elemen ke lima adalah elemen terkait OFITS yaitu bentuk segi enam sebagai bentuk dasar KJA OFITS, tampak samping susunan ke tiga bagian dari KJA OFITS, railing pada desain KJA OFITS, nelayan yang akan bekerja membantu merawat dan memanen ikaln hasil KJA, dan kasur tidur santai sebagai salah satu gambaran perabot di KJA OF ITS.

Elemen ke enam adalah elemen yang berhubungan dengan expresi suasana berlibur di sekitar laut. Pertama diwakili dengan kacamata hitam, senyum ceria seseorang dengan rambut terkibas, dua buah nanas yang biasanya identik dengan minuman jus buah dingin. Pada table solusi yang ke empat menampilkan kamera dan hasil foto-foto liburan dan yang terakhir adalah tiket, karena tanpa tiket seseorang tidak dapat masuk ke tempat-tempat wisata. Tiket juga dapat diartikan persetujuan untuk berlibur.

Tahap diatas seorang desainer melakukan pencatatan komponen yang akan digunakan dalam merancang logo sebelum tahap selanjutnya untuk melakukan kreasi yang harmoni. Harmoni didefinisikan sebagai rangsangan desain yang diberukan untuk dapat dilihat oleh konsumen sebagai pola keseluruhan.

Pencatatan komponen kemudian dikreasikan untuk alternatif rancangan identitas visual. Penulis menetapkan tiga alternatif logo yang dibentuk dari perpaduan beberapa komponen pada Gambar 7. Alternatif pertama ( lingkaran berwarna pink) dibentuk dari railing pada elemen gambar KJA, huruf E pada elemen huruf, dan ombak pada elemen gambar laut.

Alternatif kedua (lingkaran berwarna biru) dibentuk dari perpaduan elemen gambar KJA yang diwakili dengan nelayan keramba, elemen gambar kapal, elemen gambar laut, dan elemen gambar ekspresi senyum. Alternatif terakhir yaitu alternatif ketiga (lingkaran berwarna hijau) dibentuk dari komponen elemen gambar hewan laut dan kekayaan hayati laut yaitu penyu laut dan terumbu karang, dan elemen gambar laut sudut pandang dalam laut. Setelah melakukan tahap di atas selanjutnya adalah melakukan evaluasi dari ketiga alternatif yang disajikan oleh tim desain sebagaimana dapat dilihat pada gambar 5. Evaluasi yang diambil dalam pemilihan akhir desain identitas Trivesea Ecotourism adalah pemungutan suara dari seluruh peneliti sebanyak 18 orang dan tim desain sebanyak 3 orang. Sehingga diperoleh identitas visual yang mewakili spirit dari Trivesea Ecotourism, yaitu alternatif 2 (Gambar 7).

Desain akhir Trivesea Ecotourism merupakan tujuan ekowisata kelautan yang memiliki konsep identitas visual gambungan dari beberapa element (Gambar 8). Pertama bentukan heksagonal yang merupakan bentuk penyimpanan yang efektif dan kokoh dibandingkan dengan bentuk geometris yang lain, selain juga merupakan bentuk dasar dari KJA OFITS. Selanjutnya bentukan kapal merupakan ekosistem yang tidak terlepaskan dengan KJA OFITS. Kapal memiliki banyak fungsi, pertama sebagai alat transportasi pendukung ekowisata tidak hanya untuk 


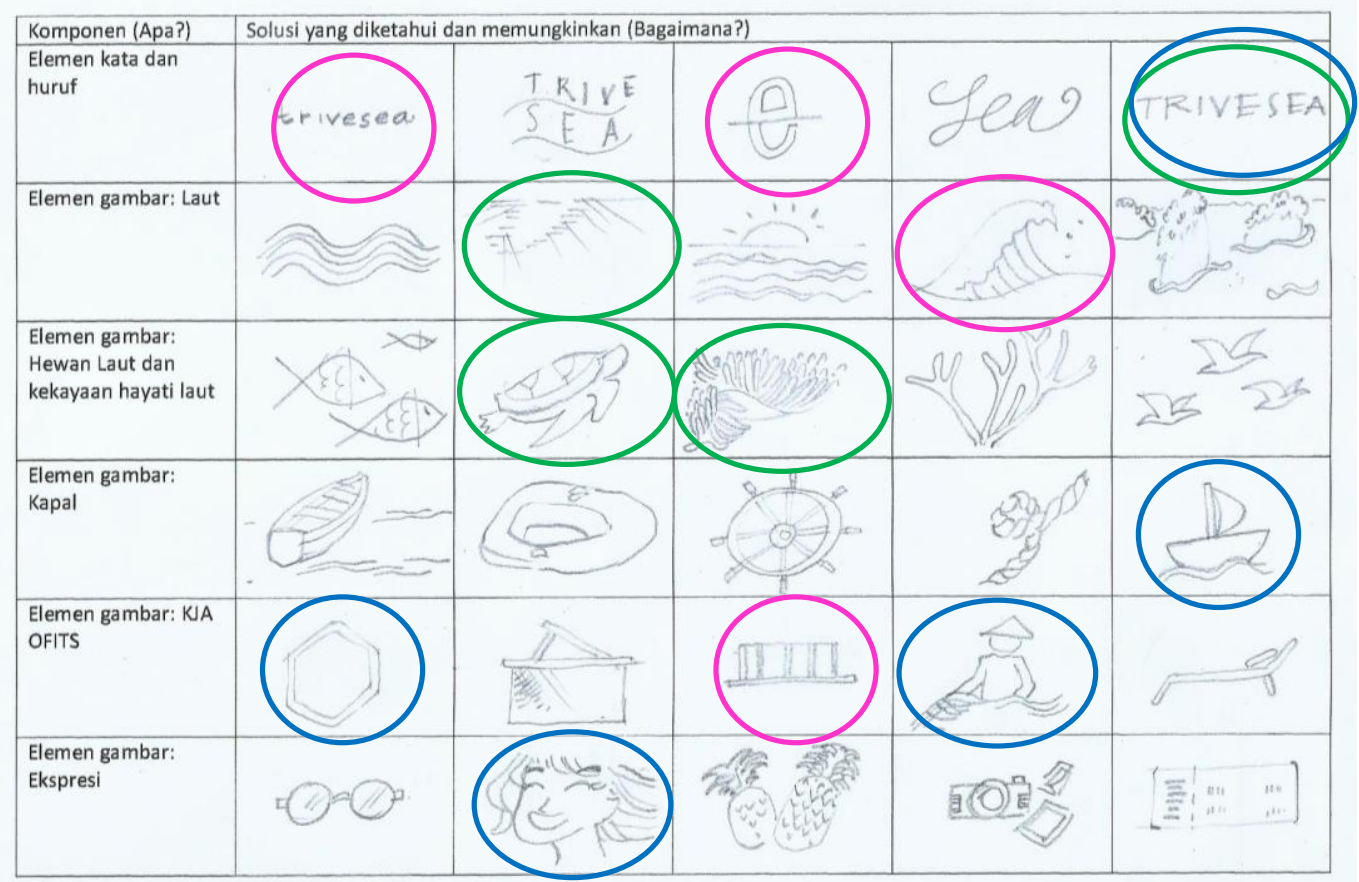

Gambar 6. Kombinasi elemen-elemen dalam komponen morphological matrix sebagai dasar ide pembentukan 3 alternatif logo. Alternatif 1 diwakili dengan warna pink, Alternatif 2 diwakili dengan warna biru, dan Alternative 3 diwakili dengan warna hijau.

membawa penumpang tetapi juga untuk membawa hasil budidaya ikan, kendaraan logistik dan kendaraan perawatan KJA OFITS.
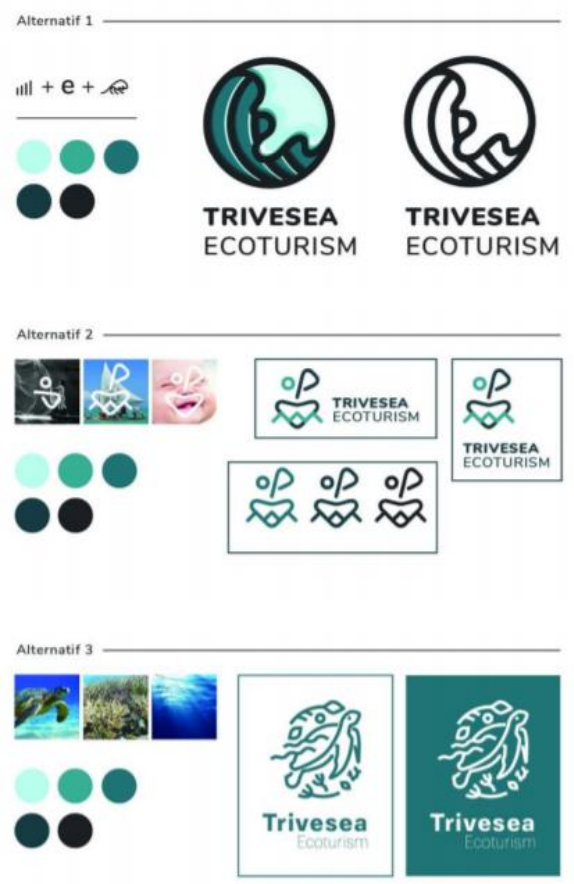

Gambar 7. Alternatif desain identitas visual dengan menggunakan morphological matrix.

Penggambaran nelayan menunjukan dalam KJA OFITS dan kegiatan pada Trivesea Ecotourism tetap melibatkan nelayan yang biasanya merupakan masyarakat lokal dimana OFITS nantinya diletakan. Keterlibatan nelayan mewakili pemberdayaan masyarakat sekitar daerah ekowisata yang akan membantu dalam membudidayakan ikan, mengolah ikan, dan mendukung ekosistem wisata pada Trivesea
Ecotourism. Ikon selanjutnya adalah ombak laut yang menampilkan basis ekowisata kelautan. Bentukan terakhir merupakan bentukan wajah yang tersenyum yang merupakan tujuan dari Trivesea Ecotourism yang ingin membawa ekowisata kelautan semakin berkembang dan memberikan kesan yang menyenangkan untuk pengunjung, dan memberikan peluang positif untuk pengembangan penelitian, peneliti KJA OFITS, pengelola dan pengembang bisnis dikemudian hari.

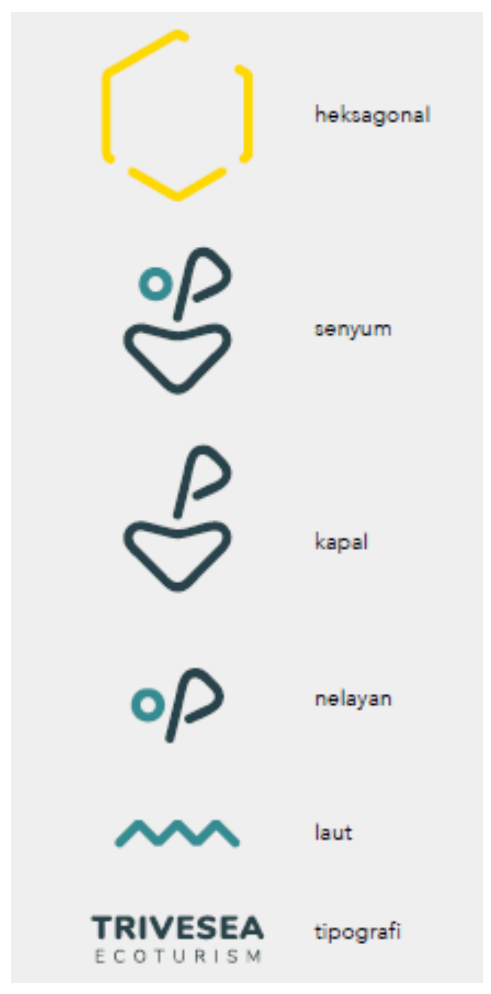

Gambar 8 Penjabaran bentuk identitas visual terpilih. 
Identitas merek menggunakan penambahan tipografi TRIVESEA yang menggunakan font Nunito yang memiliki bentuk rounded yang selaras dengan bentukan element logo dan ECOTURISM yang menggunakan font Avenir. Logo menggunakan gabungan warna biru laut dan warna kuning untuk lebih menggambarkan kesan laut yang ceria. Semua menggunakan uppercase untuk menonjolkan kekokohan pada konsep ekowisata kelautan baru namun tetap tidak terasa kaku dan lebih menyenangkan apabila dihubungkan dengan logogram yang sudah didesain.

Rancangan akhir terpilih identitas visual merek Trivesea Ecotourism (Gambar 9) merupakan kombinasi enam komponen terdiri dari elemen huruf dan elemen gambar beserta kombinasi warna sebagaimana dijabarkan diatas. Rancangan identitas visual ini selanjutnya dapat diplikasikan diberbagai media lini atas, lini bawah dan media digital kreatif.

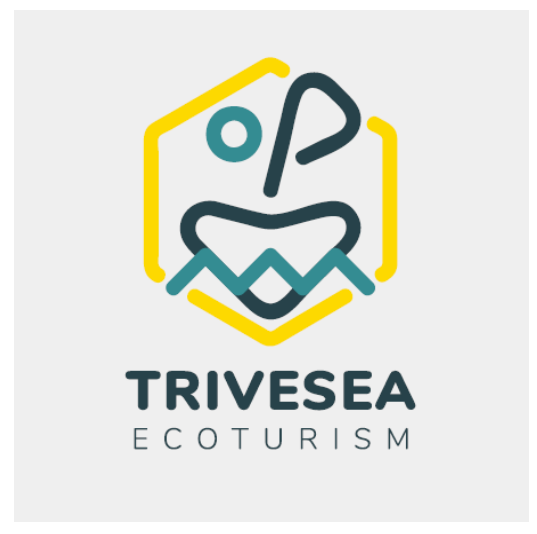

Gambar 9. Rancangan identitas visual terpilih.

\section{KESIMPULAN/RINGKASAN}

Rancang bangun Identitas Visual Ekowisata Kelautan Trivesea Ecotourism pada KJA OFITS merupakan sebuah upaya dalam pengenalan kawasan wisata buatan baru dengan menggunakan dasar bangunan KJA yang telah di rancang oleh tim Pusat Studi Kelautan LPPM-ITS. Salah satu metode kreatif dalam merancang identitas visual sebuah merek adalah dengan metode matriks morfologi.

Matrik morfologi mengakomodasi berbagai gagasan yang terhubung dengan nilai sebuah merek dan dengan melakukan reduksi grafis dan penggayaan visual menghasilkan visualisasi yang mampu menampilkan inovasi pariwisata berbasis kemaritiman.

Identitas visual Trivesea Ecotourism adalah salah satu bagian dari kegiatan branding yang mendukung aktifitas promosi yang aplikasinya diharapkan dapat menarik atensi dari investor dan wisatawan. Kegiatan branding dan promosi untuk pengembangan ekowisata dengan menggunakan modul OFITS membutuhkan atensi dari investor sebagai upaya global implementasi perancangan produk inovasi ITS juga sebagai pengembangan penelitian kolaboratif akuakultur di Pusat Studi Kelautan-LPPM ITS.
Pengembangan studi OFITS dalam kerangka inovasi produk hasil penelitian yang akan dikomersialisasi dapat dalam bentuk aktivasi merek, kegiatan promosi, pengembangan konten wisata dan edukasi, yang kesemuanya didukung dengan bentuk-bentuk kajian tentang kepariwisataan terutama pada daerah-daerah spesifik berserta studi lainnya dalam upaya perlindungan kekayaan intelektual.

\section{UCAPAN TERIMA KASIH}

Terima kasih tim peneliti berikan kepada Institut Teknologi Sepuluh Nopember (ITS) Surabaya melalui skema penelitian departemen di Departemen Komunikasi VisualITS yang telah memberikan kesempatan melakukan studi mendalam tentang identitas visual ekowisata kelautan Trivesea Ecotourism pada KJA OFITS. Ucapan terima kasih juga diberikan kepada tim peneliti Pusat Studi KelautanDRPM ITS dari berbagai disiplin ilmu yang telah memberikan waktu, tenaga dan pikiran dalam kesempurnaan penyelesaian publikasi ini.

\section{DAFTAR PUSTAKA}

[1] F. Kurniawan, L. Adrianto, D. G. Bengen, and L. B. Prasetyo, "Vulnerability assessment of small islands to tourism: The case of the Marine Tourism Park of the Gili Matra Islands, Indonesia," Glob. Ecol. Conserv., vol. 6, pp. 308-326, 2016, doi 10.1016/j.gecco.2016.04.001.

[2] K. P. R. Indonesia., Buku Panduan dan Buku Saku Manajemen Krisis Kepariwisataan. 2019.

[3] F. Kurniawan, L. Adrianto, D. G. Bengen, and L. B. Prasetyo, "The social-ecological status of small islands: An evaluation of island tourism destination management in Indonesia," Tour. Manag. Perspect., vol. 31, no. April, pp. 136-144, 2019, doi 10.1016/j.tmp.2019.04.004.

[4] M. Papageorgiou, "Coastal and marine tourism: A challenging factor in Marine Spatial Planning," Ocean Coast. Manag., vol. 129, pp. 44 48, 2016, doi: 10.1016/j.ocecoaman.2016.05.006.

[5] M. M. Foroudi, J. M. T. Balmer, W. Chen, P. Foroudi, and P. Patsala, "Explicating place identity attitudes, place architecture attitudes, and identification triad theory," J. Bus. Res., vol. 109, no March 2017, pp. 321-336, 2020, doi: 10.1016/j.jbusres.2019.12.010.

[6] K. Nickel, U. R. Orth, and M. Kumar, "Designing for the genders The role of visual harmony," Int. J. Res. Mark., no. xxxx, 2020, doi: 10.1016/j.ijresmar.2020.02.006

[7] A. Wheeler, Designing brand identity: an essential guide for the entire branding team, Fifth. Hoboken, New Jersey: John Wiley \& Sons, Inc., 2018.

[8] B. Dahl, "Brand Strategy: Branded House vs. House of Brands," 2016. https://dkyinc.com/2016/05/building-a-winning-brandstrategy-brand-hierarchy (accessed Aug. 19, 2020).

[9] M. Pricken, Creative Advertising: Ideas and Techniques from the World's Best Campaigns, New Editio. thames and hudson, 2002.

[10] P. Evans and M. Thomas, Exploring the Elements of Design: An Introduction to Essential Principles, Elements \& Concepts of Visual Communication (Design Exploration Series), Third Edit. Clifton Park, NY: Delmar Cengage Learning, 2013.

[11] R. Fenech, "MORPHOLOGICAL MATRIX," 2020. https://www.robfenech.co.uk/morphological-matrix/.

[12] L. Klint, H. Lisby, and H. A. Binthahir, "Using a PHM-based visual brand identity management system to manage deterioration of visual brand identities and prolong their life span," 2014 Int. Conf. Progn. Heal. Manag. PHM 2014, 2015, doi: 10.1109/ICPHM.2014.7036364. 